\title{
Comparison of neurons derived from mouse P19, rat PC12 and human SH-SY5Y cells in the assessment of chemical- and toxin-induced neurotoxicity
}

\author{
Dina Popova, Jessica Karlsson and Stig O. P. Jacobsson * (1)
}

\begin{abstract}
Background: Exposure to chemicals might be toxic to the developing brain. There is a need for simple and robust in vitro cellular models for evaluation of chemical-induced neurotoxicity as a complement to traditional studies on animals. In this study, neuronally differentiated mouse embryonal carcinoma P19 cells (P19 neurons) were compared with human neuroblastoma SH-SY5Y cells and rat adrenal pheochromocytoma PC12 cells for their ability to detect toxicity of methylmercury (MeHg), okadaic acid and acrylamide.
\end{abstract}

Methods: Retinoic acid-treated P19 and SH-SY5Y cells and nerve growth factor-stimulated PC12 cells, allowed to differentiate for 6 days, were exposed to MeHg, okadaic acid and acrylamide for $48 \mathrm{~h}$. Cell survival and neurite outgrowth were assessed with the calcein-AM assay and fluorescence detection of antibodies against the cytoskeletal neuron-specific protein $\beta I I I-t u b u l i n$, respectively. The effects of glutathione (GSH) and the potent inhibitor of GSH synthesis buthionine sulfoximine (BSO) on the MeHg induced-toxicity were assessed using the PrestoBlue ${ }^{\mathrm{TM}}$ cell viability assay and the TMRE mitochondrial membrane potential assay.

Results: Differentiated P19 cells developed the most extensive neuronal network among the three cell models and were the most sensitive neuronal model to detect neurotoxic effects of the test compounds. MeHg produced a concentration-dependent toxicity in differentiated P19 cells and SH-SY5Y cells, with statistically significant effects at concentrations from $0.1 \mu \mathrm{M}$ in the P19 neurons and $1 \mu \mathrm{M}$ in the SH-SY5Y cells. MeHg induced a decrease in the cellular metabolic activity and mitochondrial membrane potential $(\Delta \psi \mathrm{m})$ in the differentiated P19 cells and SH-SY5Y cells, that were attenuated by GSH. Okadaic acid and acrylamide also showed statistically significant toxicity in the P19 neurons, but not in the SH-SY5Y cells or the P12 cells.

Conclusions: P19 neurons are more sensitive to detect cytotoxicity of MeHg, okadaic acid and acrylamide than retinoic acid-differentiated SH-SY5Y cells and nerve growth factor-treated PC12 cells. P19 neurons are at least as sensitive as differentiated SH-SY5Y cells to detect the loss of mitochondrial membrane potential produced by $\mathrm{MeHg}$ and the protective effects of extracellular GSH on MeHg toxicity. P19 neurons may be a useful model to study neurotoxic effects of chemicals.

Keywords: In vitro cytotoxicity, Neuronal cell cultures, Retinoic acid-treated P19 cells, Retinoic acid-treated SH-SY5Y cells, Nerve growth factor-treated PC12 cells, Neurotoxicity, Methylmercury, Okadaic acid, Acrylamide, Glutathione

* Correspondence: stig.jacobsson@umu.se

Department of Pharmacology and Clinical Neuroscience, Umeå University,

Umeå, Sweden 


\section{Background}

Humans are exposed to a growing number of chemicals, including environmental pollutants, food preservatives, cosmetics and drugs which might be potentially toxic to the human health. Traditional toxicological studies performed on animals are time-consuming, expensive and do not yield mechanistic information. There is a need for simple and robust in vitro cellular models that allow a rapid toxicological screening of a large number of chemicals. Moreover, cellular models are useful to study specific mechanisms of chemical-induced toxicity as a complement to more complex investigations on animals [1]. With respect to in vitro models for neurotoxicity studies, a balance needs to be struck between the complexity of the model and its capacity, since there is inevitably a reciprocal relationship between these two considerations. We have focussed upon cellular models with sufficient capacity to allow for detailed mechanistic investigations. In this respect, rat pheochromocytoma PC12 cells and human neuroblastoma SH-SY5Y cells are simple and yet elegant in vitro models for neurotoxicity studies $[2,3]$.

PC12 cells originate from a rat adrenal pheochromocytoma isolated in 1976. Upon exposure to nerve growth factor (NGF), PC12 cells undergo neuronal differentiation [4]. NGF-treated PC12 cells release several neurotransmitters including dopamine [5], noradrenaline [6] and acetylcholine [7].

The human cell line SH-SY5Y is a subclone of SK-N$\mathrm{SH}$, which was isolated in 1970 from the bone marrow aspiration of a 4-year-old girl with metastatic neuroblastoma [8]. When stimulated with retinoic acid (RA), SHSY5Y differentiates to dopaminergic neuron-like cells [9].

P19 cells were isolated in 1981 from a mouse teratocarcinoma [10]. The P19 cell line is multipotent, it can differentiate into derivates from all three germ layers: endoderm, mesoderm, and neuroectoderm. Upon exposure to RA, P19 differentiate predominantly into neuronal-like cells (P19 neurons), but also astroglia and fibroblast-like cells [11]. P19 neurons are postmitotic and possess functional synapses $[12,13]$. Several excitatory and inhibitory neurotransmitters and associated receptors and enzymes have been detected in P19 neurons, including glutamate, GABA, and acetylcholine [14-19].

In this study, neuronally differentiated mouse embryonal carcinoma P19 cells have been compared with human neuroblastoma SH-SY5Y cells and rat pheochromocytoma PC12 cells for their ability to respond to the toxicity of methylmercury (MeHg), okadaic acid and acrylamide.

$\mathrm{MeHg}$ is an organic form of the heavy metal mercury. Mercury is transformed to $\mathrm{MeHg}$ in bacteria [20] and bioaccumulates in fish [21]. The primary route of human exposure is consumption of seafood. $\mathrm{MeHg}$ is highly toxic to the central nervous system and particularly to the developing brain [22]. One of the key targets of $\mathrm{MeHg}$ toxicity is the glutathione (GSH) antioxidant system [23-25]. In mouse, in utero exposure to $\mathrm{MeHg}$ leads to reduced GSH levels and inhibits the activity of glutathione peroxidase and glutathione reductase in the developing brain [25]. In human neurons, astrocytes and SH-SY5Y cells, extracellular treatment with $\mathrm{GSH}$ protects against $\mathrm{MeHg}$ induced cytotoxicity. Moreover, buthionine sulfoximine (BSO), a potent inhibitor of GSH synthesis [26] increases MeHg-induced toxicity in these cell types [24].

Another key target of $\mathrm{MeHg}$ cytotoxicity is the mitochondria. $\mathrm{MeHg}$ induces mitochondrial dysfunctions in different neuronal cell types and tissues [27-30], among them loss of mitochondrial membrane potential $(\Delta \psi \mathrm{m})$ has been detected in mouse hippocampal HT22 cell line [27] and neonatal rat primary cerebellar granule cells [28].

$\mathrm{MeHg}$ inhibits microtubule polymerization in the cytoskeleton in vitro [31, 32], an important process for maintaining cell structure and viability [33]. $\mathrm{MeHg}$ also inhibits neurite outgrowth and causes neurite degeneration in studies on animals and in in vitro cellular models [2, 34-36].

Okadaic acid is a marine biotoxin responsible for diarrheal shellfish poisoning. It is a potent inhibitor of protein phosphatases [37]. Neurotoxicity of this compound has been observed both in in vitro $[38,39]$ and in vivo studies [40, 41].

Acrylamide is widely used in the industry over the world and it also forms naturally in starch containing food cooked at high temperatures [42]. Studies on animals [43, 44] and in cellular models [3] have shown neurotoxicity of acrylamide.

In the present study, we have compared the sensitivity of the three described cell lines towards $\mathrm{MeHg}$, okadaic acid and acrylamide during the process of neuronal development. The use of the three cell lines allows delineation of both common and cell-specific neurotoxic mechanisms for a given compound.

The effects of the chemicals on cell survival and neurite outgrowth were investigated. Cell viability was assessed with the calcein-AM assay that measures intracellular esterase activity. Neurite outgrowth was assessed using immunocytochemical labeling of BIII-tubulin, a component of microtubules in the cytoskeleton specific for nerve cells [45]. In addition, the role of GSH on MeHg-induced effects on cellular metabolic reduction, extracellular lactate dehydrogenase (LDH) release and mitochondrial membrane potential were assessed in RA-treated P19 and SH-SY5Y cells.

\section{Methods}

Chemicals

Dulbecco's modified Eagle's medium with high glucose (DMEM), minimal essential medium with Earl's salts 
(EMEM), Dulbecco's modified medium with Ham's F12 medium (DMEM/F12), poly-D-lysine hydrobromide, dimethyl sulfoxide (DMSO), all-trans retinoic acid (RA), rat nerve growth factor $\beta$ (NGF $\beta$ ), okadaic acid, methylmercury (II) chloride, acrylamide, DL-Buthionine$[\mathrm{S}, \mathrm{R}]$-sulfoximine (BSO), L-glutathione reduced (GSH), tetramethylrhodamine ethyl ester perchlorate (TMRE) and bovine serum albumin were purchased from SigmaAldrich (Stockholm, Sweden). MEM- $\alpha$ medium containing deoxyribonucleosides and ribonucleosides ( $\alpha M E M)$, neurobasal medium, B27 supplement, N2 supplement, fetal bovine serum (FBS), L-glutamine, non-essential amino acids (NEAA), trypsin/EDTA solution, heat-inactivated horse serum (HS), penicillin/ streptomycin (PEST), trypan blue, Alexa Fluor 488 goat anti-rabbit antibodies, Hanks' balanced salt solution (HBSS) with $\mathrm{CaCl}_{2}$ and $\mathrm{MgCl}_{2}$, PrestoBlue ${ }^{\mathrm{Tm}}$ cell viability reagent and calcein-AM were purchased from Invitrogen Life Technologies (Uppsala, Sweden). Triton X-100 and EDTA were obtained from MERCK (Darmstadt, Germany). Purified polyclonal rabbit antibody BIII-tubulin was purchased from Convance Inc. (Princeton, New Jersey, USA). Cytotoxicity detection kit (LDH) was obtained from Roche Diagnostics (Mannheim, Germany). Formaldehyde solution (4\%) was purchased from Apotek Produktion \& Laboratorier (Umea, Sweden).

\section{Cell culture and neuronal differentiation}

P19 mouse embryonal carcinoma cells (cat. no. ECACC 95102107), PC12 rat adrenal pheochromocytoma cells (cat. no. ECACC 88022401) and SH-SY5Y human neuroblastoma cells (cat. no. ECACC 94030304) were obtained from European Collection of Authenticated Cell Cultures (ECACC) (Porton Down, UK).

P19 cells were cultured in $\alpha$ MEM medium (10\% FBS, $1 \% \mathrm{NEAA}, 1 \mathrm{IU} / \mathrm{ml}$ penicillin and $1 \mu \mathrm{g} / \mathrm{ml}$ streptomycin) in T75 flasks. The cultures were split 1:20-1:100 at $70-80 \%$ of confluence using $0.05 \%$ trypsin $/ 0.02 \%$ EDTA solution in PBS ( 3 min incubation at $37{ }^{\circ} \mathrm{C}, 5 \% \mathrm{CO}_{2}$ ).

The neuronal differentiation was induced according to the protocol of Yao et al. [19]. The cells were maintained in Neurobasal medium containing B27 supplement as reported in Svensson et al. [18]. The process of neuronal differentiation of P19 cells included two steps: induction with retinoic acid (RA) (4 days) and differentiation up to 10 days. The cells were plated on a bacterial-grade petri dish (Ø92 mm, Sarstedt Inc., Newton, NC) $\left(1 \times 10^{6}\right.$ cells/ dish) in $\alpha M E M$ medium (5\% FBS, 1\% NEAA, $1 \mathrm{IU} / \mathrm{ml}$ penicillin and $1 \mu \mathrm{g} / \mathrm{ml}$ streptomycin). RA $(1 \mu \mathrm{M})$ was added to induce the process of differentiation. The medium was replaced after $48 \mathrm{~h}$. After totally $96 \mathrm{~h}$ of induction with RA, the cells $\left(500\right.$ cells $\left./ \mathrm{mm}^{2}\right)$ were plated on poly-D-lysine coated $(0.05 \mathrm{mg} / \mathrm{ml})$ black clear bottom 96 -well plates in Neurobasal medium containing 2\% B27 supplement,
$0.5 \mathrm{mM}$ L-glutamine, $1 \mathrm{IU} / \mathrm{ml}$ penicillin and $1 \mu \mathrm{g} / \mathrm{ml}$ streptomycin. Half of the medium/well was replaced every second day.

PC12 cells were cultured in poly-D-lysine coated $(0.05 \mathrm{mg} / \mathrm{ml})$ T75 flasks in DMEM medium $(10 \% \mathrm{HS}$, $1 \% \mathrm{FBS}$ and $1 \mathrm{IU} / \mathrm{ml}$ penicillin and $1 \mu \mathrm{g} / \mathrm{ml}$ streptomycin). Approximately $70 \%$ of the medium was changed every second or third day. The cells were grown to 70 $80 \%$ of confluence and split 1:3-4 using $0.5 \mathrm{mM}$ EDTA solution in PBS (5 min incubation at $37{ }^{\circ} \mathrm{C}, 5 \% \mathrm{CO}_{2}$ followed by gentle cell scraping). PC12 cells were induced to neuronal differentiation using nerve growth factor [4] essentially as described by $\mathrm{Li}$ et al. [46] with the following modifications. PC12 cells were differentiated in DMEM medium (1\% $\mathrm{HS}, 1 \mathrm{IU} / \mathrm{ml}$ penicillin and $1 \mu \mathrm{g} / \mathrm{ml}$ streptomycin) freshly supplemented with $100 \mathrm{ng} / \mathrm{ml}$ rat NGFB. The cells $\left(500\right.$ cells $\left./ \mathrm{mm}^{2}\right)$ were plated in black clear bottom 96-well plates in the culture medium overnight. Next day, the medium was replaced with the differentiation medium. Every second day, half of the medium/well was changed.

SH-SY5Y cells were cultured in EMEM medium (10\% FBS, 1\% NEAA, $2 \mathrm{mM}$ L-glutamine, $1 \mathrm{IU} / \mathrm{ml}$ penicillin and $1 \mu \mathrm{g} / \mathrm{ml}$ streptomycin) in T75 flasks. Medium was changed every third to fourth day. The cells were grown to $70-80 \%$ of confluence and split to 10,000 cells $/ \mathrm{cm}^{2}$ or 25,000 cells $/ \mathrm{cm}^{2}$. To passage the cells, $0.05 \%$ Trypsin/ $0.02 \%$ EDTA solution in PBS was applied for $5 \mathrm{~min}$ at $37{ }^{\circ} \mathrm{C}, 5 \% \mathrm{CO}_{2}$. Differentiation of SH-SY5Y cells was performed with $1 \mu \mathrm{M}$ RA in DMEM F12 (1:1) medium (1\% N2, $1 \mathrm{IU} / \mathrm{ml}$ penicillin and $1 \mu \mathrm{g} / \mathrm{ml}$ streptomycin) [47]. The cells were plated at a density of 500 cells $/ \mathrm{mm}^{2}$ in black clear bottom 96-well plates in the culture medium overnight. The day after, the medium was changed to the differentiation medium. Half of the medium/ well was replaced every second day.

\section{Chemical exposure}

The cell lines were plated at a density of 500 cells $/ \mathrm{mm}^{2}$ in 96-well plates. $\mathrm{MeHg}$ and okadaic acid were dissolved in DMSO. The final concentration of DMSO in the samples was $0.1 \%$. Acrylamide was dissolved in PBS. Buthionine sulfoximine (BSO) and reduced glutathione (GSH) were dissolved in Milli-Q water. On day 6 in the differentiation media, the cells were exposed to $\mathrm{MeHg}(0.05-1 \mu \mathrm{M})$, okadaic acid $(0.5-10 \mathrm{nM})$ and acrylamide $(0.1-1000 \mu \mathrm{M})$ for $48 \mathrm{~h}$. To investigate the importance of glutathione status on MeHg-induced toxicity, cells were pretreated with BSO $(100 \mu \mathrm{M})$ for $17 \mathrm{~h}$ or GSH $(1 \mathrm{mM})$ for $1 \mathrm{~h}$ prior to $\mathrm{MeHg}(1 \mu \mathrm{M})$ exposure for $24 \mathrm{~h}$.

\section{Cell viability analyses}

Calcein-AM is a fluorescence-based cell viability assay. The non-fluorescent compound calcein-acetoxymethyl 
(AM) enters the cells where intracellular esterases remove the AM group. The fluorescent calcein is retained in the living cells, and it can be detected at the excitation/emission maximum of 495/550 $\mathrm{nm}$ [48, 49]. Samples were washed with PBS and incubated with $1 \mu \mathrm{M}$ calcein- $\mathrm{AM}$ for $1 \mathrm{~h}$ at room temperature protected from light. The fluorescence was measured in BMG FLOUstar Galaxy microplate reader (BMG Lab technologies, Offenburg, Germany) with 490/520 nm excitation/emission filters. Representative images of the samples were taken with a Nikon Eclipse TE2000-U inverted microscope with a Plan Fluor ELWD 20×/0.45 objective with a Nikon Digital Sight DS-5Mc camera (Tekno Optik AB, Skärholmen, Sweden). Samples treated with $2 \%$ Triton $\mathrm{X}-100$ for $30 \mathrm{~min}$ at $37{ }^{\circ} \mathrm{C}, 5 \%$ $\mathrm{CO}_{2}$ served as controls for maximal cell death.

Cellular metabolic reduction was measured with PrestoBlue $^{\mathrm{Th}}$ resazurin-based assay. PrestoBlue reagent $(10 \mu \mathrm{L} /$ well $)$ was added to $100 \mu \mathrm{l}$ of cells in media. After $30 \mathrm{~min}$ of incubation at $37{ }^{\circ} \mathrm{C}, 5 \% \mathrm{CO}_{2}$, fluorescence was measured in the FLUOstar Galaxy plate reader with 544/612 $\mathrm{nm}$ excitation/emission filters. LDH activity in cell culture media that indicate damage to the cell membrane was assessed with LDH cytotoxicity detection kit according to the manufacturer's instructions. Cell culture media $(100 \mu \mathrm{l} /$ well $)$ were transferred to a clear 96-well plate and $100 \mu \mathrm{l}$ of the kit reagent mixture was added. After $30 \mathrm{~min}$ of incubation at room temperature, absorbance was measured at $490 \mathrm{~nm}$ (reference wavelength $650 \mathrm{~nm}$ ) in the SPECTROstar Nano microplate reader (BMG LABTECH GmbH, Offenburg, Germany). The media from cells treated with $2 \%$ Triton X-100 solution for $30 \mathrm{~min}$ at $37{ }^{\circ} \mathrm{C}, 5 \% \mathrm{CO}_{2}$ were used to detect the maximal $\mathrm{LDH}$ content in the medium.

\section{Immunofluorescence detection of $\beta$ III-tubulin}

The samples were fixed in $4 \%$ formaldehyde for $30 \mathrm{~min}$, permeabilized with $0.1 \%$ Triton $\mathrm{X}-100$ for $5 \mathrm{~min}$, and washed three times with PBS. To minimize unspecific antibody binding, blocking solution (3\% FBS in PBS) was applied for $30 \mathrm{~min}$. The purified polyclonal antibodies against BIII-tubulin diluted 1:500 in 3\% FBS were added to the cells for $1 \mathrm{~h}$ incubation. The samples were washed three times with PBS, and the secondary antibodies Alexa Fluor 488, diluted 1:250 in 3\% FBS, were applied for $1 \mathrm{~h}$. After three washes in PBS, fluorescence in the samples was measured in the FLOUstar Galaxy microplate reader with $485 / 520 \mathrm{~nm}$ excitation/emission filters. Representative images of the samples were obtained using a Nikon Eclipse TE2000-U inverted microscope with a Plan Fluor ELWD 20x/0.45 objective with a Nikon Digital Sight DS-5Mc camera. The samples exposed to $2 \%$ Triton $\mathrm{X}-100$ for $30 \mathrm{~min}$ at $37{ }^{\circ} \mathrm{C}, 5 \% \mathrm{CO}_{2}$ were used as controls of the minimal amount of fluorescence in dead cells.

\section{Mitochondrial membrane potential $\left(\Delta \Psi_{\mathrm{m}}\right)$ analysis}

Alterations in mitochondrial membrane potential was measured with TMRE (tetramethylrhodamine ethyl ester) assay. TMRE is a positively charged dye that accumulates in negatively charged mitochondria. Less dye accumulates in inactive or depolarized mitochondria due to their less negative charge compared to polarized or active mitochondria [50]. TMRE (1 mM) stock solution was prepared in DMSO and stored at $-20{ }^{\circ} \mathrm{C}$. The stock solution was diluted in the cell culture media to the working solution of $5 \mu \mathrm{M}$ TMRE. In the cell samples, the medium was changed and TMRE was added to the final concentration of $500 \mathrm{nM}$ for 30-45 min incubation at $37{ }^{\circ} \mathrm{C}, 5 \% \mathrm{CO}_{2}$. The cells were washed once with $100 \mu \mathrm{l}$ of HBSS containing $0.2 \%$ bovine serum albumin (BSA), and $200 \mu \mathrm{l}$ of $\mathrm{HBSS} / 0.2 \%$ BSA was added to the samples. Fluorescence was measured in the FLUOstar Galaxy plate reader with $544 / 590 \mathrm{~nm}$ excitation/emission filters.

\section{Statistical analysis}

Three to six independent experiments were performed for each assay with triplicates or duplicates for each experimental condition. Statistical analyses (one- or twoway ANOVA for repeated measures with Dunnett's or Bonferroni's post hoc multiple comparisons tests) were undertaken in the GraphPad Prism computer program for the Macintosh, version 6 (GraphPad Software Inc., San Diego, CA, USA).

\section{Results}

Neuronal differentiation of the P19, PC12 and SH-SY5Y cell lines

The process of neurite outgrowth during differentiation (days 2-10) was assessed using immunostaining against $\beta$ III-tubulin. The representative images of the cells are shown in Fig. 1a, and the fluorescence intensities (expressed in relative fluorescence units) of the secondary antibodies bound to anti- $\beta$ III-antibodies are present in Fig. 1b. RA-treated P19 cells showed the most complex neuronal network, with neurite elongation and branching, among the three cell models (Fig. 1a). The amount of BIII-tubulin fluorescence increased as the process of neuronal differentiation proceeded in P19 and SH-SY5Y cells and to a lesser extent in PC12 cells. The P19 cells did not proliferate in the serum-free differentiation medium, and the increase in the amount of $\beta$ IIItubulin fluorescence was due to an increase in neurite extensions [51]. SH-SY5Y cells continued to proliferate during the process of differentiation. Therefore, the increase in BIII-tubulin fluorescence was due to the 


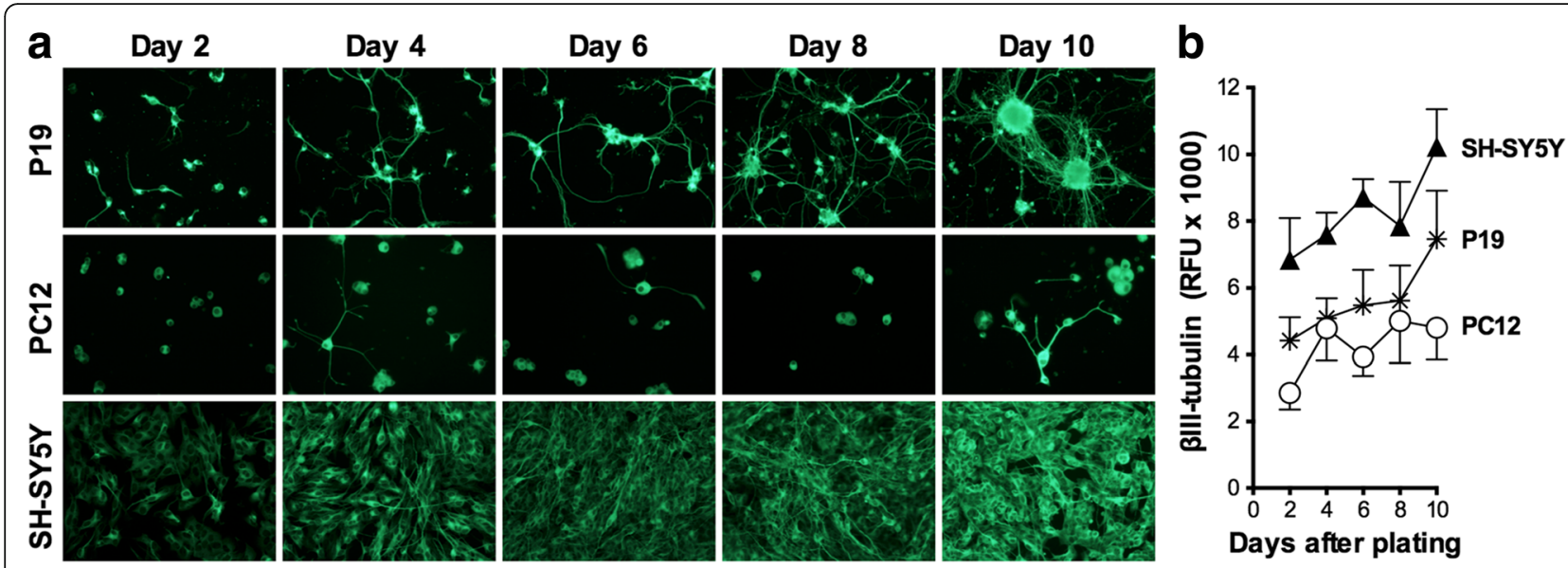

Fig. 1 Development of neurons derived from RA-treated P19 and SH-SY5Y cells, and NGF-stimulated PC12 cells up to 10 days in culture. The cells were plated at a density of 500 cells $/ \mathrm{mm}^{2}$ and immunostained against the neuron-specific protein $\beta$ III-tubulin. a Representative fluorescence microscopy images of neurons ( $20 \times$ magnification). $\mathbf{b}$ Fluorescence of anti- $\beta l l$-tubulin antibodies measured in a microplate reader and expressed as relative fluorescence units (RFU). Data are means \pm SEM of 3-4 independent experiments

increasing number of cells in addition to neurite extensions. Less number of PC12 cells possessed neurites compared to the other two models explaining lower increase in $\beta$ III-tubulin fluorescence (Fig. 1a and b).

\section{Effects of MeHg, okadaic acid and acrylamide upon neuronal viability}

Differentiated P19 cells were more sensitive towards the toxicity produced by $\mathrm{MeHg}$, okadaic acid and acrylamide compared to PC12 cells and SH-SY5Y cells, as assessed by calcein-AM assay and immunofluorescence detection of $\beta$ III-tubulin (Fig. 2). MeHg produced a concentrationdependent toxicity in the P19 neurons, with statistically significant effects at concentrations from $0.5 \mu \mathrm{M}$ and higher in the calcein-AM assay, and from $0.1 \mu \mathrm{M}$ and higher in the BIII-tubulin assay. Fluorescence (expressed as $\%$ of controls) seen following treatment with $0.5 \mu \mathrm{M}$ of $\mathrm{MeHg}$ in the P19 neurons was $77 \pm 10 \%$ (means \pm SEM; Fig. 2a) and $78 \pm 9 \%$ (Fig. 2b) for the calcein-AM and $\beta$ III-tubulin methodologies, respectively. In P12 cells, corresponding treatment showed $90 \pm 13 \%$ and $88 \pm 1 \%$, and in SH-SY5Y cells $86 \pm 11 \%$ and $93 \pm 6 \%$, respectively. There was a tendency for concentration-dependent toxic effects of MeHg in the PC12 cells and the SH-SY5Y cells, but the only statistically significant effect was obtained in the SH-SY5Y cells at a concentration of $1 \mu \mathrm{M}$, when measuring the fluorescence of calcein $(p<0.05)$. However, a two-way ANOVA of all $\mathrm{MeHg}$ data showed that $\mathrm{MeHg}$ produced a statistically significant decrease in the fluorescence of calcein $(p<0.001)$ and BIII-tubulin $(p<0.01)$, independently of the cell type examined (no interaction between concentrations of $\mathrm{MeHg} \times$ cell type).

The potent cytotoxin okadaic acid, at a concentration of $10 \mathrm{nM}$, produced a significant reduction in cytosolic fluorescence of calcein in the P19 neurons $(75 \pm 6 \%$ of untreated controls; $p<0.05$ ) (Fig. 2c). One-way ANOVA (with post hoc Dunnett's multiple comparisons test) of the okadaic acid data revealed no other statistically significant effects. However, a two-way ANOVA of the same data showed that okadaic acid produced a statistically significant $(p<0.001)$ decrease in the fluorescence

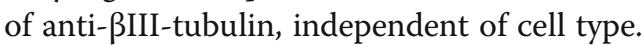

Acrylamide did not significantly affect the viability of the examined cell lines, except in the P19 neurons where $1 \mathrm{mM}$ acrylamide reduced the fluorescence of calcein to $87 \pm 3 \%$ of untreated controls (Fig. 2e; $p<0.05$ ). Representative images of the cells exposed to $\mathrm{MeHg}(1 \mu \mathrm{M})$, okadaic acid (10 $\mathrm{nM})$ and acrylamide $(1 \mathrm{mM})$ immunostained against $\beta$ III-tubulin are shown in Fig. 3. In the fluorescence microscopy images, exposure of differentiated P19, PC12 and SH-SY5Y cells to $1 \mu \mathrm{M} \mathrm{MeHg}$ and $10 \mathrm{nM}$ okadaic acid destroyed the neurites. Acrylamide (1 mM) partially damaged the neurites in P19 and PC12 cells, and to a lesser extent in SH-SY5Y cells (Fig. 3). The images show the examples of the cells labeled against BIII-tubulin and treated with the compounds, and do not provide a quantitative information about the effects of the chemicals on these cells. Fluorescence plate reader measurements of the cells shown in Fig. 2 quantify the effects of the chemicals on the fluorescence of anti-ßIII-tubulin antibodies.

\section{Involvement of GSH in the MeHg-induced toxicity in differentiated P19 and SH-SY5Y cells}

To investigate if the toxicity produced by $\mathrm{MeHg}$ is affected by alterations of intracellular glutathione status, differentiated P19 and SH-SY5Y cells were preincubated with GSH or BSO. In P19 neurons and differentiated 


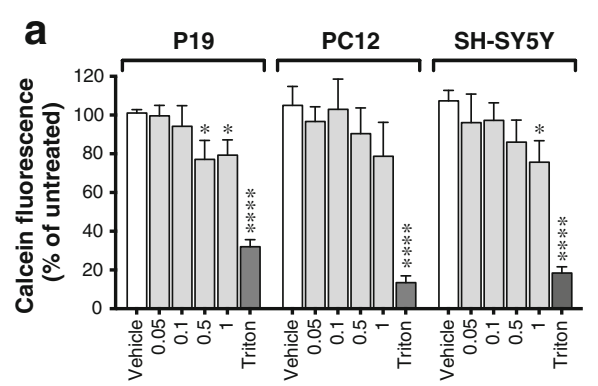

[Methylmercury] $(\mu \mathrm{M})$
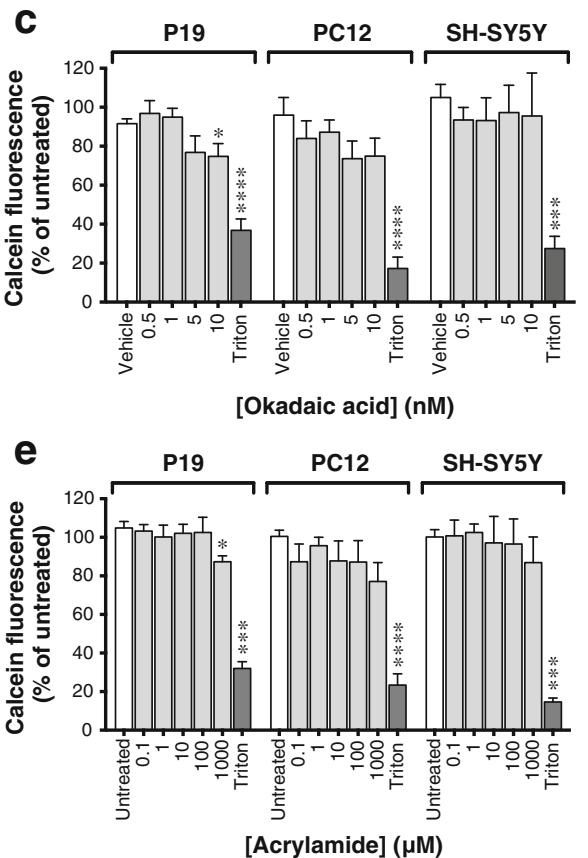

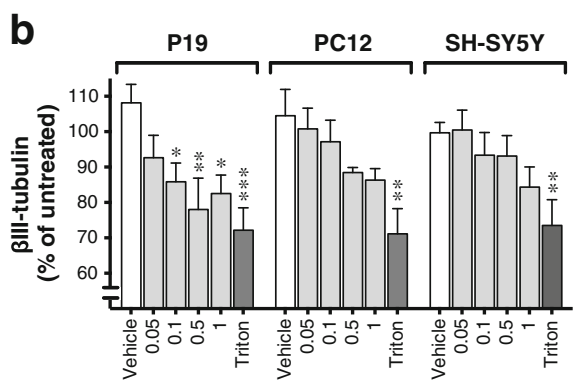

[Methylmercury] ( $\mu \mathrm{M})$

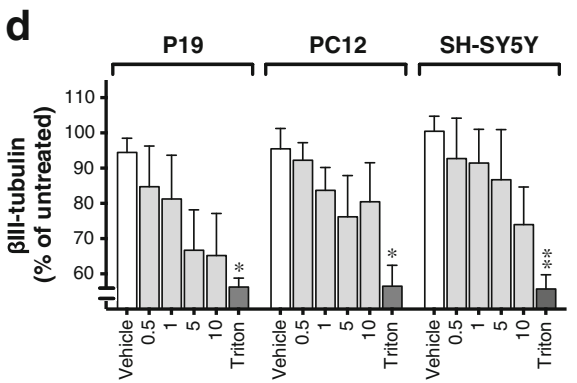

[Okadaic acid] (nM)

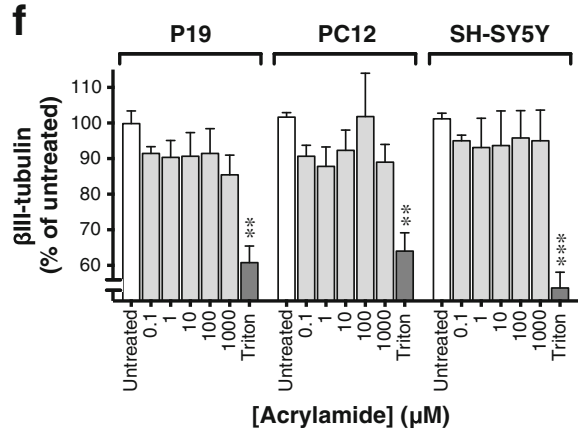

Fig. 2 Concentration-dependent effects of MeHg, okadaic acid and acrylamide on cell viability and expression of the neuron-specific protein $\beta$ III-tubulin in neuronally differentiated P19, PC12 and SH-SY5Y cells. The cells were plated at a density of $500 \mathrm{cells} / \mathrm{mm}^{2}$ and cultured for 6 days in the differentiation media, followed by exposure to the test compounds for $48 \mathrm{~h}$. Effects of $\mathrm{MeHg}(\mathbf{a}, \mathbf{b})$, okadaic acid $(\mathbf{c}, \mathbf{d})$ and acrylamide $(\mathbf{e}$, $\mathbf{f})$ on the cell viability were assessed by using the calcein-AM assay $(\mathbf{a}, \mathbf{c}, \mathbf{e})$, and the immunofluorescence of $\beta$ III-tubulin $(\mathbf{b}, \mathbf{d}$, $\mathbf{f}$ ). The data are means \pm SEM of $n=6$ independent experiments ( $n=3$ for okadaic acid in the Blll-tubulin assay; panel $\mathbf{d}$ ). The results are expressed as percentage of non-treated cells or cells treated with $0.1 \%$ DMSO (used as vehicle). Wells treated with $2 \%$ Triton X-100 for 30 min served as controls for maximal cell death. Statistical analysis was performed using repeated measures one-way ANOVA with post hoc Dunnett's multiple comparisons test ${ }^{*} p<0.05,{ }^{* *} p<0.01,{ }^{* * *} p<0.001$, and ${ }^{* * * *} p<0.0001$ ) compared to corresponding controls

SH-SY5Y cells, preincubation with GSH reduced the MeHg toxicity as measured with both the PrestoBlue (Fig. 4) and the TMRE assays (Fig. 5). MeHg, at a concentration of $1 \mu \mathrm{M}$, produced a major statistically significant decrease in the cellular metabolic activity $(35 \pm 2 \%$ of vehicle controls in $\mathrm{P} 19$ neurons and $47 \pm 8 \%$ in SHSY5Y cells), with a simultaneous increase in extracellular LDH activity from $7 \pm 1 \%$ (of total LDH content) in P19 controls to $15 \pm 1 \%$, and from $13 \pm 2 \%$ in SH-SY5Y controls to $32 \pm 3 \%$ (Fig. 4). Similar results were obtained in the TMRE assay (Fig. 5) where $1 \mu \mathrm{M} \mathrm{MeHg}$ reduced $\Delta \Psi \mathrm{m}$ to $59 \pm 2 \%$ of controls in the P19 neurons and to $60 \pm 4 \%$ in the SH-SY5Y cells. Preincubation with $1 \mathrm{mM}$ GSH for $1 \mathrm{~h}$ attenuated the MeHg-induced decrease in
PrestoBlue reduction and TMRE fluorescence in both cell lines (by approximately $30 \%$ or more in all assays). Exposure to $1 \mathrm{mM} \mathrm{GSH}$ for $25 \mathrm{~h}$ significantly decreased TMRE fluorescence in both cell models. In the treated P19 neurons and retinoic acid-differentiated SH-SY5Y cells, the TMRE fluorescence was $72 \pm 4 \%$ and $77 \pm 6 \%$, respectively. The detected decrease in mitochondrial membrane potential might have been the consequence of the reductive stress produced by the excessive GSH levels in the cells [52]. No valid data of the effect of GSH in the LDH assay could be obtained, since GSH seems to directly interfere with the LDH test readout by producing abnormally high absorbance values. Preincubation with $100 \mu \mathrm{M}$ BSO for $17 \mathrm{~h}$ significantly enhanced 


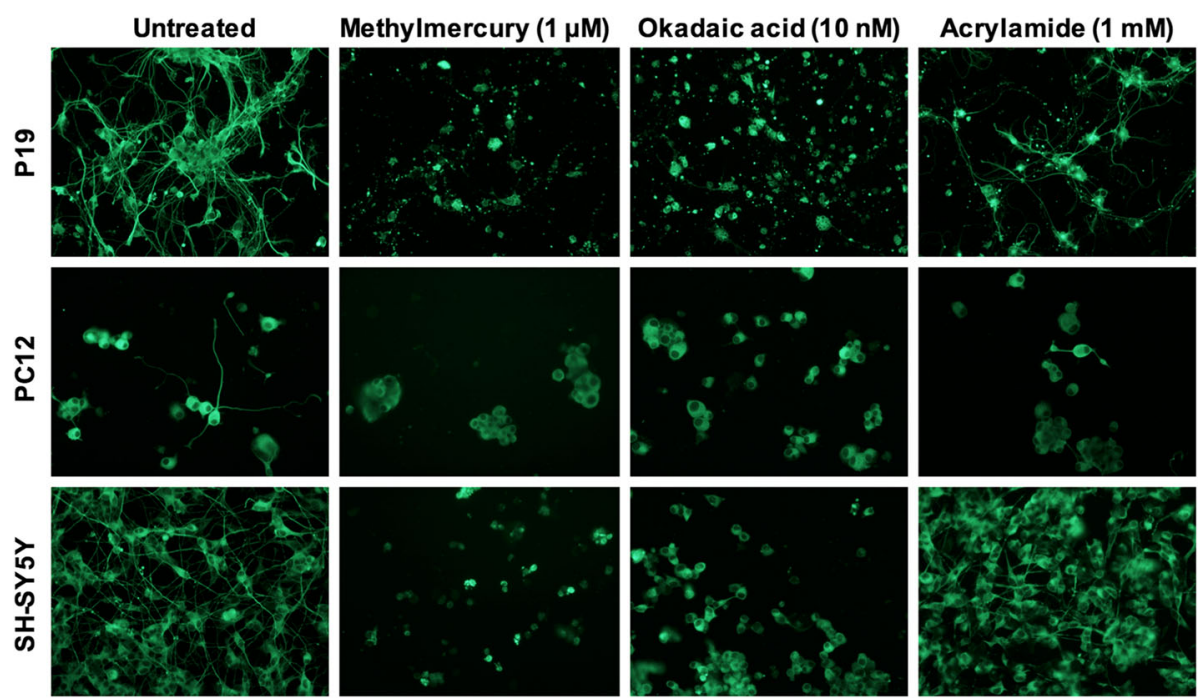

Fig. 3 Representative fluorescence microscopy images of neuronally differentiated P19, PC12 and SH-SY5Y cells exposed to $1 \mu \mathrm{M}$ methylmercury, $10 \mathrm{nM}$ okadaic acid and $1 \mathrm{mM}$ acrylamide. The cells were plated at a density of 500 cells $/ \mathrm{mm}^{2}$ and cultured for 6 days in the differentiation media, followed by exposure to the test compounds for $48 \mathrm{~h}$. The cells were immunolabeled against the neuron-specific protein $\beta$ III-tubulin and the fluorescence microscopy images were obtained at $20 \times$ magnification
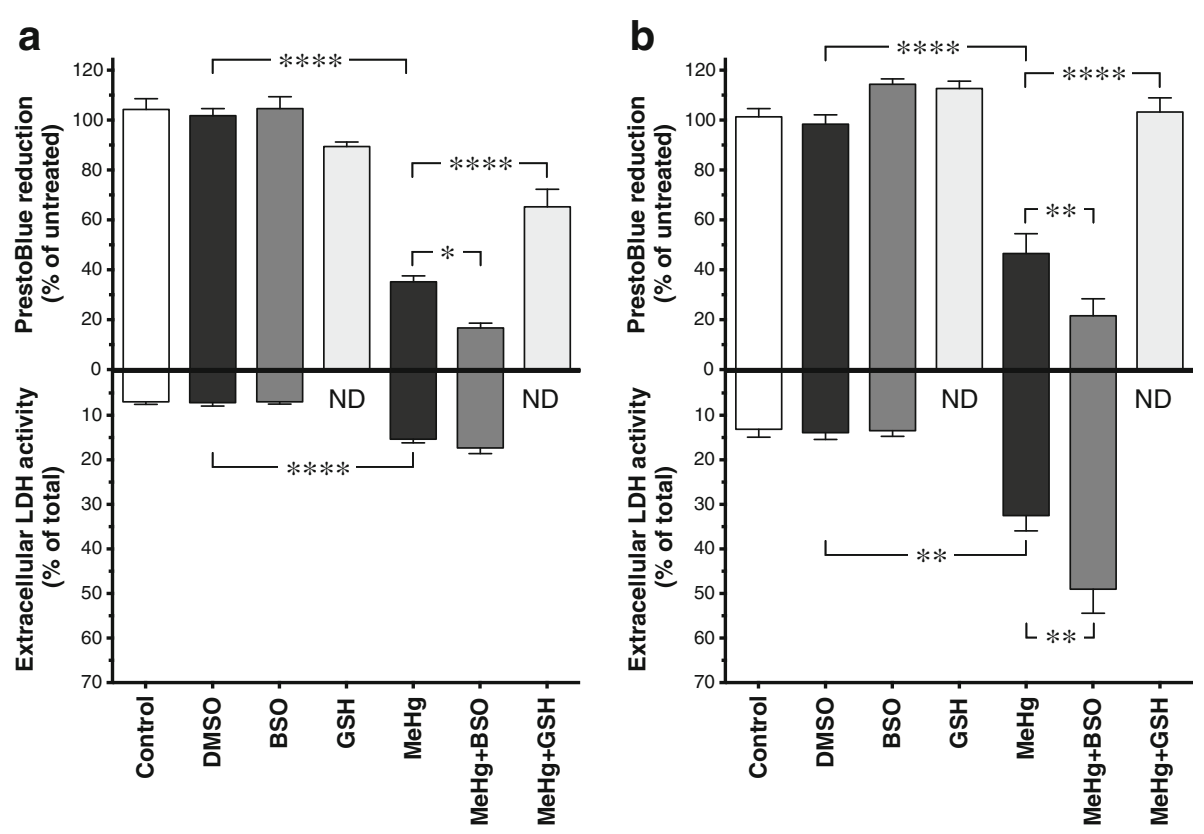

Fig. 4 Effects of MeHg, BSO and GSH on the viability of RA-treated P19 cells (a) and SH-SY5Y cells (b). Cells cultured for 6 days in the differentiation media were pre-treated with $100 \mu \mathrm{M}$ BSO for $17 \mathrm{~h}$ or $1 \mathrm{mM} \mathrm{GSH}$ for $1 \mathrm{~h}$ followed by exposure to $1 \mu \mathrm{M} \mathrm{MeHg}$ for $24 \mathrm{~h}$. Cell viability was assessed with the PrestoBlue assay that measures cellular metabolic reduction, and extracellular LDH activity assay. Data are means \pm SEM of $n=6$ independent experiments. For the PrestoBlue assay, data are expressed as percentage of non-treated or $0.1 \%$ DMSO vehicle-treated cells. For the LDH assay, the data are presented as percentage of total cell death (cells treated with $2 \%$ Triton X-100). Statistical analysis was undertaken using one-way ANOVA with post hoc Bonferroni's multiple comparisons test: ${ }^{*} p<0.05,{ }^{* *} p<0.01$, and ${ }^{* * * *} p<0.0001$ (the effect of the treatment compared to the corresponding vehicle control, or the effect of the combination of $\mathrm{MeHg}+\mathrm{GSH}$ or MeHg + BSO compared to MeHg per se). ND = not determined 

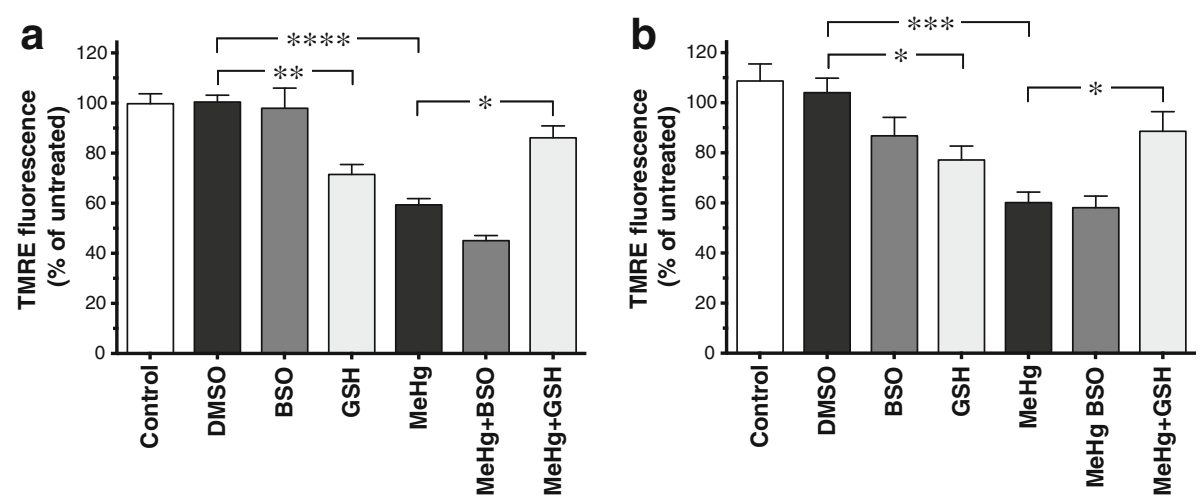

Fig. 5 The effects of MeHg, GSH and BSO on TMRE fluorescence in RA-treated P19 (a) and SH-SY5Y cells (b). Cells cultured for 6 days in the differentiation media were pre-treated with $100 \mu \mathrm{M} \mathrm{BSO}$ for $17 \mathrm{~h}$ or with $1 \mathrm{mM} \mathrm{GSH}$ for $1 \mathrm{~h}$ followed by exposure to $1 \mu \mathrm{M}$ MeHg for $24 \mathrm{~h}$. Alterations in mitochondrial membrane potential were measured with the TMRE assay. Data are means \pm SEM of $n=6$ independent experiments, and expressed as percentage of non-treated or $0.1 \%$ DMSO vehicle-treated cells. Statistical analysis was undertaken using one-way ANOVA with post hoc Bonferroni's multiple comparisons test: ${ }^{*} p<0.05,{ }^{* *} p<0.01,{ }^{* * *} p<0.001$, and ${ }^{* * *} p<0.0001$ (the effect of the treatment compared to the corresponding vehicle control, or the effect of the combination of MeHg + GSH or MeHg + BSO compared to MeHg per se)

the MeHg-induced effects on cellular metabolic activity in both cell lines (to $16 \pm 2 \%$ of P19 controls and $22 \pm$ $7 \%$ of SH-SY5Y controls; Fig. 4), and the extracellular LDH activity in the SH-SY5Y cultures increased to $49 \pm$ $5 \%$. No statistically significant effects of BSO on the MeHg-induced decrease in mitochondrial membrane potential could be observed (Fig. 5).

\section{Discussion}

With an increasing number of chemicals in the environment, there is a need for simple and robust in vitro cellular models for detection of their potential toxic effects. The purpose of this work was to evaluate the sensitivity of three different neuronal cell models, towards detection of chemical-induced neurotoxicity. Neurons derived from P19 cells were the most sensitive model in the neurotoxicity assessment of $\mathrm{MeHg}$, okadaic acid and acrylamide. Decrease in intracellular fluorescence of calcein and amount of anti- $\beta$ III-tubulin immunofluorescence upon the exposure to the compounds was detected at lower concentrations in P19 neurons than in differentiated SH-SY5Y and PC12 cells.

The SH-SY5Y human neuroblastoma cell line has been long used as an in vitro neuronal model in neuroprotection and Parkinson's disease research mainly due to its human origin and catecholaminergic properties [53]. The rat PC12 cells have been widely used to study the process of neuronal differentiation and regulation of neurite development $[54,55]$, but also to study vesicle function and exocytosis [56]. Previous studies have shown that both PC12 cells and SH-SY5Y cells are vulnerable to $\mathrm{MeHg}$-induced neurotoxicity upon exposure in the beginning of the differentiation processes. In RA- treated SH-SY5Y cells, MeHg was toxic at lower concentrations when co-introduced with RA in the start of the differentiation process than after 2 days of differentiation [57]. In NGF-treated PC12 cells, MeHg reduced cell viability and inhibited neurite outgrowth at the initiation of the differentiation process at the low micromolar concentrations [2].

We found that the neuronally differentiated P19 cells is a more robust and sensitive model to detect $\mathrm{MeHg}$ induced cytotoxicity compared to differentiated PC12 and SH-SY5Y cells. The mouse P19 cells have been used for many types of studies on neuronal development. A major advantage in neurotoxicology studies is that the P19 cells can differentiate into a wide range of neuronal and glial cell types with robust expression of GABAergic and glutamatergic phenotypes and the ability to form functional synapses [14] in contrast to most commonly used cell lines. The tumorigenic background of the P19 cell has been, however, considered a disadvantage compared to, for example, human stem cells. However, it is less expensive and time-consuming to maintain and differentiate P19 cells to neurons compared to human stem cells [58].

The known targets of $\mathrm{MeHg}$ toxicity include the glutathione system [25] and the mitochondria [27]. We showed that extracellular GSH exposure reduced MeHginduced toxicity in both RA-treated P19 cells and SHSY5Y cells. BSO, the potent inhibitor of GSH synthesis, enhanced the negative effect of MeHg upon cellular metabolic activity. The results are in line with the study of Sanfeliu et al. [24] in which GSH and BSO exposure had similar effects on the toxicity of $\mathrm{MeHg}$ in human neurons, astrocytes and SH-SY5Y cells. Although, in our 
study, treatment with extracellular GSH alone decreased mitochondrial membrane potential that might have been caused by the reductive stress that affected mitochondria [52]. In the study of Zhang et al. [52], exposure of the embryonic rat myocardial cell line $\mathrm{H} 9 \mathrm{c} 2$ to $\mathrm{N}$-acetyl ${ }_{L^{-}}$ cysteine (NAC), the precursor of GSH, led to increased levels of GSH, mitochondrial oxidation and cytotoxicity. Singh et al. [59] demonstrated that $24 \mathrm{~h}$ treatment of the rat skeletal muscle cell line L6 with $1 \mathrm{mM}$ NAC did not affect cell viability but increased production of superoxides that are damaging to cells. However, in the study on different mammalian cell lines, treatment with NAC and GSH ethyl ester, caused a rapid mitochondrial oxidation that did not involve alterations in mitochondrial membrane potential measured with the TMRE probe [60].

Okadaic acid has been shown to inhibit neurite outgrowth in NGF-treated PC12 cells at low nanomolar concentrations [61], and in cultured rat cortical neurons and the human neuroblastoma cell line MSN, okadaic acid induced changes in neuronal cytoskeleton that led to cell death [62]. In the present study, okadaic acid showed a tendency to concentration-dependently reduced the fluorescence of anti- $\beta$ III-tubulin in all cell types, but the great variance of the data precluded from obtaining statistical significance. However, in the P19 neurons, at a concentration of $10 \mathrm{nM}$, okadaic acid showed a statistically significant reduction in the fluorescence of calcein. This enlightens the importance of using several different methods to assess the neurotoxicity of chemicals which often in dose-response studies show what could be described as threshold effects.

Acrylamide significantly reduced cell viability in P19 cells at the concentration of $1 \mathrm{mM}$, but not in the PC12 or SH-SY5Y cells. Although, in the study of Attoff et al. [3] acrylamide applied to SH-SY5Y cells in the beginning of the differentiation process for 3-6 days greatly reduced cell proliferation at the same concentration. Additionally, the same study reported that acrylamide impaired neurite outgrowth at the concentration of $100 \mathrm{nM}$ after 3 days of exposure. That might indicate that SH-SY5Y cells are more susceptible to acrylamide neurotoxicity at the early stage of differentiation and/or at longer times of exposure than examined in the present study. In NGF $(50 \mathrm{ng} / \mathrm{ml}$ )-stimulated $\mathrm{PC} 12$ cells, Chen et al. [63] showed that acrylamide inhibited cells proliferation at the concentration of $0.5 \mathrm{mM}$, and at $0.1 \mathrm{mM}$ reduced neurite outgrowth after $48 \mathrm{~h}$ of exposure. The exposure to acrylamide was performed directly at the start of the differentiation process along with NGF treatment. Therefore, acrylamide might be more toxic when applied at the early stage of cell differentiation compare to the later stage assessed in our study.

\section{Conclusions}

The P19 neurons were more sensitive to detect general cytotoxicity of $\mathrm{MeHg}$, okadaic acid and acrylamide than the PC12 cells and the SH-SY5Y cells during neuronal differentiation. Additionally, P19 neurons had the most complex structure of neuronal network compared to SH-SY5Y and PC12 cells. P19 neurons were also able to detect specific targets of MeHg toxicity as the GSH system and the mitochondria. Therefore, the P19 neuronal model may have an application as an in vitro cell model for screening of chemicals for neurotoxic effects and for evaluation of specific mechanism of toxicity especially during the process of neuronal development. The main limitation of the model includes the mouse carcinoma origin. The advantages include a simple and robust model with many properties of mammalian brain cells in culture, that is less expensive to maintain than human stem cells.

\section{Abbreviations \\ BSO: Buthionine sulfoximine; calcein-AM: Calcein-acetoxymethyl; GABA: Gamma-aminobutyric acid; GSH: Glutathione; LDH: Lactate dehydrogenase; MeHg: Methylmercury; NAC: N-acetyl-_-cysteine; NGF: Nerve growth factor; RA: Retinoic acid; TMRE: Tetramethylrhodamine ethyl ester}

\section{Acknowledgements}

We want to thank Professor Christopher J. Fowler for the suggestions on some of the experiments.

\section{Funding}

This work was supported by the Research Funds of Umeå University Medical Faculty (to SOPJ). The funders had no role in study design, data collection and analysis, decision to publish, or preparation of the manuscript.

\section{Availability of data and materials}

The datasets used and/or analysed during the current study available from the corresponding author on reasonable request.

\section{Authors' contributions}

DP participated in the study design, carried out $2 / 3$ of experiments, analysed data and wrote the manuscript. JK performed $1 / 3$ of the experiments,

analysed the data and made suggestions on the manuscript. SOPJ designed the study and wrote the manuscript. All authors read and approved the final manuscript.

\section{Competing interests}

The authors declare that they have no competing interests.

Consent for publication

Not applicable.

Ethics approval and consent to participate

Not applicable.

\section{Publisher's Note}

Springer Nature remains neutral with regard to jurisdictional claims in published maps and institutional affiliations.

Received: 8 March 2017 Accepted: 26 May 2017

Published online: 05 June 2017

References

1. Harry GJ, Billingsley M, Bruinink A, Campbell IL, Classen W, Dorman DC, et al. In vitro techniques for the assessment of neurotoxicity. Environ Health Perspect. 1998;106 Suppl 1:131-58. 
2. Parran DK, Mundy WR, Barone Jr S. Effects of methylmercury and mercuric chloride on differentiation and cell viability in PC12 cells. Toxicol Sci. 2001; 59:278-90.

3. Attoff K, Kertika D, Lundqvist J, Oredsson S, Forsby A. Acrylamide affects proliferation and differentiation of the neural progenitor cell line C17.2 and the neuroblastoma cell line SH-SY5Y. Toxicol In Vitro. 2016:35:100-11.

4. Greene LA, Tischler AS. Establishment of a noradrenergic clonal line of rat adrenal pheochromocytoma cells which respond to nerve growth factor. Proc Natl Acad Sci U S A. 1976;73:2424-8.

5. Amino S, Itakura M, Ohnishi H, Tsujimura J, Koizumi S, Takei N, et al. Nerve growth factor enhances neurotransmitter release from PC12 cells by increasing $\mathrm{Ca}(2+)$-responsible secretory vesicles through the activation of mitogen-activated protein kinase and phosphatidylinositol 3-kinase. J Biochem. 2002;131:887-94.

6. Chu E, Chu J, Socci RR, Chu TC. 7-OH-DPAT-induced inhibition of norepinephrine release in PC12 cells. Pharmacology. 2004;70:130-9.

7. Greene LA, Rukenstein A. Regulation of acetylcholinesterase activity by nerve growth factor. Role of transcription and dissociation from effects on proliferation and neurite outgrowth. J Biol Chem. 1981;256:6363-7.

8. Biedler JL, Helson L, Spengler BA. Morphology and growth, tumorigenicity, and cytogenetics of human neuroblastoma cells in continuous culture. Cancer Res. 1973;33:2643-52.

9. Korecka JA, van Kesteren RE, Blaas E, Spitzer SO, Kamstra JH, Smit AB, et al. Phenotypic characterization of retinoic acid differentiated SH-SY5Y cells by transcriptional profiling. PLoS One. 2013;8:e63862.

10. McBurney MW, Rogers BJ. Isolation of male embryonal carcinoma cells and their chromosome replication patterns. Dev Biol. 1982;89:503-8.

11. Jones-Villeneuve EM, McBurney MW, Rogers KA, Kalnins VI. Retinoic acid induces embryonal carcinoma cells to differentiate into neurons and glial cells. J Cell Biol. 1982;94:253-62.

12. McBurney MW, Reuhl KR, Ally Al, Nasipuri S, Bell JC, Craig J. Differentiation and maturation of embryonal carcinoma-derived neurons in cell culture. J Neurosci. 1988;8:1063-73

13. Morassutti DJ, Staines WA, Magnuson DS, Marshall KC, McBurney MW. Murine embryonal carcinoma-derived neurons survive and mature following transplantation into adult rat striatum. Neuroscience. 1994:58:753-63.

14. Finley MF, Kulkarni N, Huettner JE. Synapse formation and establishment of neuronal polarity by P19 embryonic carcinoma cells and embryonic stem cells. J Neurosci. 1996;16:1056-65.

15. MacPherson PA, Jones S, Pawson PA, Marshall KC, McBurney MW. P19 cells differentiate into glutamatergic and glutamate-responsive neurons in vitro. Neuroscience. 1997;80:487-99.

16. Ray WJ, Gottlieb DI. Expression of ionotropic glutamate receptor genes by P19 embryonal carcinoma cells. Biochem Biophys Res Commun. 1993;197:1475-82.

17. Parnas $D$, Linial M. Acceleration of neuronal maturation of P19 cells by increasing culture density. Brain Res Dev Brain Res. 1997;101:115-24.

18. Svensson AC, Johansson M, Persson E, Carchenilla MS, Jacobsson SO. Expression of functional CB1 cannabinoid receptors in retinoic aciddifferentiated P19 embryonal carcinoma cells. J Neurosci Res. 2006:83:1128-40.

19. Yao M, Bain G, Gottlieb DI. Neuronal differentiation of P19 embryonal carcinoma cells in defined media. J Neurosci Res. 1995:41:792-804.

20. Schaefer JK, Rocks SS, Zheng W, Liang L, Gu B, Morel FM. Active transport, substrate specificity, and methylation of $\mathrm{Hg}(\mathrm{II})$ in anaerobic bacteria. Proc Natl Acad Sci U S A. 2011;108:8714-9.

21. Souza-Araujo J, Giarrizzo T, Lima MO, Souza MB. Mercury and methyl mercury in fishes from Bacaja River (Brazilian Amazon): evidence for bioaccumulation and biomagnification. J Fish Biol. 2016;89:249-63.

22. Ekino S, Susa M, Ninomiya T, Imamura K, Kitamura T. Minamata disease revisited: an update on the acute and chronic manifestations of methyl mercury poisoning. J Neurol Sci. 2007;262:131-44.

23. Choi BH, Yee $\mathrm{S}$, Robles $\mathrm{M}$. The effects of glutathione glycoside in methyl mercury poisoning. Toxicol Appl Pharmacol. 1996;141:357-64.

24. Sanfeliu C, Sebastia J, Ki SU. Methylmercury neurotoxicity in cultures of human neurons, astrocytes, neuroblastoma cells. Neurotoxicology. 2001;22:317-27.

25. Stringari J, Nunes AK, Franco JL, Bohrer D, Garcia SC, Dafre AL, et al. Prenatal methylmercury exposure hampers glutathione antioxidant system ontogenesis and causes long-lasting oxidative stress in the mouse brain Toxicol Appl Pharmacol. 2008;227:147-54.

26. Griffith OW. Mechanism of action, metabolism, and toxicity of buthionine sulfoximine and its higher homologs, potent inhibitors of glutathione synthesis. J Biol Chem. 1982;257:13704-12.
27. Tofighi R, Johansson C, Goldoni M, Ibrahim WN, Gogvadze V, Mutti A, et al. Hippocampal neurons exposed to the environmental contaminants methylmercury and polychlorinated biphenyls undergo cell death via parallel activation of calpains and lysosomal proteases. Neurotox Res. 2011; 19:183-94.

28. Limke TL, Atchison WD. Acute exposure to methylmercury opens the mitochondrial permeability transition pore in rat cerebellar granule cells. Toxicol Appl Pharmacol. 2002;178:52-61.

29. Dreiem A, Seegal RF. Methylmercury-induced changes in mitochondrial function in striatal synaptosomes are calcium-dependent and ROSindependent. Neurotoxicology. 2007;28:720-6.

30. Levesque PC, Atchison WD. Disruption of brain mitochondrial calcium sequestration by methylmercury. J Pharmacol Exp Ther. 1991;256:236-42.

31. Sager PR, Doherty RA, Olmsted JB. Interaction of methylmercury with microtubules in cultured cells and in vitro. Exp Cell Res. 1983;146:127-37.

32. Vogel DG, Margolis RL, Mottet NK. The effects of methyl mercury binding to microtubules. Toxicol Appl Pharmacol. 1985;80:473-86.

33. Poulain FE, Sobel A. The microtubule network and neuronal morphogenesis: dynamic and coordinated orchestration through multiple players. Mol Cell Neurosci. 2010;43:15-32.

34. Fujimura M, Usuki F, Sawada M, Rostene W, Godefroy D, Takashima A. Methylmercury exposure downregulates the expression of Racl and leads to neuritic degeneration and ultimately apoptosis in cerebrocortical neurons. Neurotoxicology. 2009;30:16-22.

35. Fujimura M, Usuki F. Methylmercury causes neuronal cell death through the suppression of the TrkA pathway: in vitro and in vivo effects of TrkA pathway activators. Toxicol Appl Pharmacol. 2015;282:259-66.

36. Fujimura M, Usuki F, Cheng J, Zhao W. Prenatal low-dose methylmercury exposure impairs neurite outgrowth and synaptic protein expression and suppresses TrkA pathway activity and eEF1A1 expression in the rat cerebellum. Toxicol Appl Pharmacol. 2016;298:1-8.

37. Takai A, Bialojan C, Troschka M, Ruegg JC. Smooth muscle myosin phosphatase inhibition and force enhancement by black sponge toxin. FEBS Lett. 1987;217:81-4.

38. Kim D, Su J, Cotman CW. Sequence of neurodegeneration and accumulation of phosphorylated tau in cultured neurons after okadaic acid treatment. Brain Res. 1999;839:253-62.

39. Malchiodi-Albedi F, Petrucci TC, Picconi B, losi F, Falchi M. Protein phosphatase inhibitors induce modification of synapse structure and tau hyperphosphorylation in cultured rat hippocampal neurons. J Neurosci Res. 1997:48:425-38

40. He J, Yamada K, Zou LB, Nabeshima T. Spatial memory deficit and neurodegeneration induced by the direct injection of okadaic acid into the hippocampus in rats. J Neural Transm (Vienna). 2001;108:1435-43.

41. Kamat PK, Tota S, Shukla R, Ali S, Najmi AK, Nath C. Mitochondrial dysfunction: a crucial event in okadaic acid (ICV) induced memory impairment and apoptotic cell death in rat brain. Pharmacol Biochem Behav. 2011;100:311-9.

42. Exon JH. A review of the toxicology of acrylamide. J Toxicol Environ Health B Crit Rev. 2006:9:397-412.

43. Tian SM, Ma YX, Shi J, Lou TY, Liu SS, Li GY. Acrylamide neurotoxicity on the cerebrum of weaning rats. Neural Regen Res. 2015;10:938-43.

44. Jangir BL, Mahaprabhu R, Rahangadale S, Bhandarkar AG, Kurkure NV. Neurobehavioral alterations and histopathological changes in brain and spinal cord of rats intoxicated with acrylamide. Toxicol Ind Health. 2016;32:526-40.

45. Katsetos CD, Legido A, Perentes E, Mork SJ. Class III beta-tubulin isotype: a key cytoskeletal protein at the crossroads of developmental neurobiology and tumor neuropathology. J Child Neurol. 2003;18:851-66.

46. Li R, Kong $Y$, Ladisch S. Nerve growth factor-induced neurite formation in PC12 cells is independent of endogenous cellular gangliosides. Glycobiology. 1998;8:597-603.

47. Gustafsson H, Runesson J, Lundqvist J, Lindegren H, Axelsson V, Forsby A. Neurofunctional endpoints assessed in human neuroblastoma SH-SY5Y cells for estimation of acute systemic toxicity. Toxicol Appl Pharmacol. 2010;245: 191-202.

48. Lichtenfels R, Biddison WE, Schulz H, Vogt AB, Martin R. CARE-LASS (calceinrelease-assay), an improved fluorescence-based test system to measure cytotoxic T lymphocyte activity. J Immunol Methods. 1994;172:227-39.

49. Roden MM, Lee KH, Panelli MC, Marincola FM. A novel cytolysis assay using fluorescent labeling and quantitative fluorescent scanning technology. J Immunol Methods. 1999;226:29-41. 
50. Perry SW, Norman JP, Barbieri J, Brown EB, Gelbard HA. Mitochondrial membrane potential probes and the proton gradient: a practical usage guide. Biotechniques. 2011;50:98-115.

51. Popova D, Jacobsson SO. A fluorescence microplate screen assay for the detection of neurite outgrowth and neurotoxicity using an antibody against betalll-tubulin. Toxicol In Vitro. 2014;28:411-8.

52. Zhang H, Limphong P, Pieper J, Liu Q, Rodesch CK, Christians E, et al. Glutathione-dependent reductive stress triggers mitochondrial oxidation and cytotoxicity. FASEB J. 2012;26:1442-51.

53. Xicoy H, Wieringa B, Martens GJ. The SH-SY5Y cell line in Parkinson's disease research: a systematic review. Mol Neurodegener. 2017;12:10,

54. Heidemann SR, Lamoureux P, Buxbaum RE. Cytomechanics of axonal development. Cell Biochem Biophys. 1995;27:135-55.

55. Messing RO. Ethanol as an enhancer of neural differentiation. Alcohol Alcohol Suppl. 1993;2:289-93.

56. Fukuda M, Kanno E, Ogata Y, Saegusa C, Kim T, Loh YP, et al. Nerve growth factor-dependent sorting of synaptotagmin IV protein to mature dense-core vesicles that undergo calcium-dependent exocytosis in PC12 cells. J Biol Chem. 2003;278:3220-6.

57. Kim YJ, Kim YS, Kim MS, Ryu JC. The inhibitory mechanism of methylmercury on differentiation of human neuroblastoma cells. Toxicology. 2007;234:1-9.

58. Hu BY, Weick JP, Yu J, Ma LX, Zhang XQ, Thomson JA, et al. Neural differentiation of human induced pluripotent stem cells follows developmental principles but with variable potency. Proc Natl Acad Sci U S A. 2010;107:4335-40

59. Singh F, Charles AL, Schlagowski Al, Bouitbir J, Bonifacio A, Piquard F, et al. Reductive stress impairs myoblasts mitochondrial function and triggers mitochondrial hormesis. Biochim Biophys Acta. 1853;2015:1574-85.

60. Kolossov VL, Beaudoin JN, Ponnuraj N, DiLiberto SJ, Hanafin WP, Kenis PJ, et al. Thiol-based antioxidants elicit mitochondrial oxidation via respiratory complex III. Am J Physiol Cell Physiol. 2015;309:C81-91.

61. Chiou JY, Westhead EW. Okadaic acid, a protein phosphatase inhibitor inhibits nerve growth factor-directed neurite outgrowth in PC12 cells. J Neurochem. 1992:59:1963-6.

62. Arias C, Sharma N, Davies P, Shafit-Zagardo B. Okadaic acid induces early changes in microtubule-associated protein 2 and tau phosphorylation prior to neurodegeneration in cultured cortical neurons. J Neurochem. 1993;61: 673-82.

63. Chen JH, Lee DC, Chiu IM. Cytotoxic effects of acrylamide in nerve growth factor or fibroblast growth factor 1-induced neurite outgrowth in $\mathrm{PC} 12$ cells, Arch Toxicol. 2014;88:769-80.

\section{Submit your next manuscript to BioMed Central and we will help you at every step:}

- We accept pre-submission inquiries

- Our selector tool helps you to find the most relevant journal

- We provide round the clock customer support

- Convenient online submission

- Thorough peer review

- Inclusion in PubMed and all major indexing services

- Maximum visibility for your research

Submit your manuscript at www.biomedcentral.com/submit

) Biomed Central 